Nowoczesne Systemy Zarządzania

Zeszyt 12 (2017), nr 4 (październik-grudzień)

ISSN 1896-9380, s. 77-92

Modern Management Systems

Volume 12 (2017), No. 4 (October-December)

ISSN 1896-9380, pp. 77-92
Instytut Organizacji i Zarządzania

Wydział Cybernetyki

Wojskowa Akademia Techniczna

w Warszawie

Institute of Organization and Management

Faculty of Cybernetics

Military University of Technology

\title{
Szkolenie funkcjonariuszy służb granicznych jako istotny instrument rozwoju zawodowego i bezpieczeństwa państwa
}

\author{
Training of border guards officers \\ as an important instrument professional \\ development and state security
}

\author{
Kazimierz Piotrkowski \\ Wojskowa Akademia Techniczna
}

\begin{abstract}
Abstrakt. Artykuł dotyczy szkolenia funkcjonariuszy służb granicznych jako istotnego instrumentu ich rozwoju zawodowego wpływającego na bezpieczeństwa naszego państwa. Na wstępie przedstawiono istotę i znaczenie szkolenia funkcjonariuszy służby granicznej w kontekście ich pożądanych kompetencji. Kolejno zaprezentowano główne instrumenty rozwoju zawodowego wpływające na rozwój kapitału ludzkiego funkcjonariuszy w Straży Granicznej. Przedstawiono ogólną klasyfikację i charakterystykę metod i technik szkolenia wpisujących się w system kształcenia i rozwoju zawodowego funkcjonariuszy Straży Granicznej. Zaprezentowano model szkolenia i doskonalenia zawodowego funkcjonariuszy Służby Granicznej w określonych korpusach osobowych.
\end{abstract}

Słowa kluczowe: szkolenie, rozwój zawodowy, bezpieczeństwo państwa.

Abstract: Focus article covers important issue on training for border services officers as an important instrument of their professional development affecting the security of our Member States. At the outset, it shows the essence and the importance of training of border services officers in the context of their desired competency. Go to the main instruments of professional development that affects the development of human capital officers in the border guards. Shows the overall classification and characteristics of the methods and techniques of training of an overall system of education and professional development of border guards. To learn the model training and in-service training of border Services officers plotted the bodies. Keywords: training, professional development, state security. 


\section{Wstęp}

Służba graniczna z punktu widzenia nauk o zarządzaniu jest zaklasyfikowana do instytucji publicznych. Stanowi ona ważny element systemu bezpieczeństwa państwa. Wpływa na ochronę naszych granic, jednocześnie zapewniając ład wewnętrzny oraz ochronę obywateli. Sprawne i skuteczne funkcjonowanie Służby Granicznej zależy od czynnika ludzkiego, który uczestniczy we wszystkich procesach zarządczych i wykonawczych. Dlatego też od zatrudnionych pracowników jako funkcjonariuszy służb granicznych wymaga się profesjonalizmu w zakresie wykonywania przez nich obowiązków służbowych. W celu zapewnienia wysokiego poziomu w wypełnianiu funkcji służbowych oraz realizacji określonych zadań niezbędne jest systematyczne szkolenie i doskonalenie, które są podstawą w nabywaniu i rozwoju kompetencji w zakresie realizacji określonych zadań wynikających ze specyfiki zawodowej. W codziennej pracy zawodowej stosowane są również nowoczesne koncepcje i metody zarządzania wpływające na sprawniejszą realizację tych zadań i doskonalsze funkcjonowanie organizacji.

\section{Istota, rola kształcenia i szkolenia funkcjonariuszy służb granicznych}

Szkolenie i doskonalenie stanowią ważny instrument rozwoju zawodowego pracowników i postrzega się je jako ważną inwestycję, która przynosi wymierne korzyści dla organizacji i samego pracownika (rys. 1). Praktycznie przejawia się $\mathrm{w}$ profesjonalnym wykonywaniu określonych zadań przez zatrudnionych $\mathrm{w}$ organizacji pracowników (funkcjonariuszy), co przekłada się również na efektywność organizacyjną. Szczególne znaczenie mają szkolenia w służbie państwowej, jaką jest praca funkcjonariuszy służb granicznych. Szkolenie tych funkcjonariuszy ma wieloaspektowy i wielopłaszczyznowy wymiar w zależności od rodzaju stanowiska służbowego i pełnionej funkcji w hierarchii organizacji.

Każdy praktycznie realizowany system kształcenia i szkolenia jest przedsięwzięciem zbiorowym. W sposób kompleksowy powinien harmonizować cele ogólne organizacji, potrzeby jej poszczególnych części i aspiracje indywidualnych pracowników. Jego efekty powinny się przekładać na działalność operacyjną wpływającą na poprawę i doskonalenie sprawności zarówno zespołów pracowniczych, jak i działalności indywidualnej. Pod uwagę bierze się w perspektywie zarówno rozwój zasobów ludzkich w ujęciu strategicznym, jak i efektywne kierowanie procesem zatrudnienia. Ważne staje się ukształtowanie kompetencji zatrudnionych pracowników w pożądanym wymiarze, a co za tym idzie, dostosowanie do określonych założeń strategicznych (pod względem ich przydatności i elastyczności), ale także to, aby stały się źródłem wprowadzania przyszłych zmian umożliwiających trwanie i rozwój w warunkach coraz większej zmienności i konkurencji. 


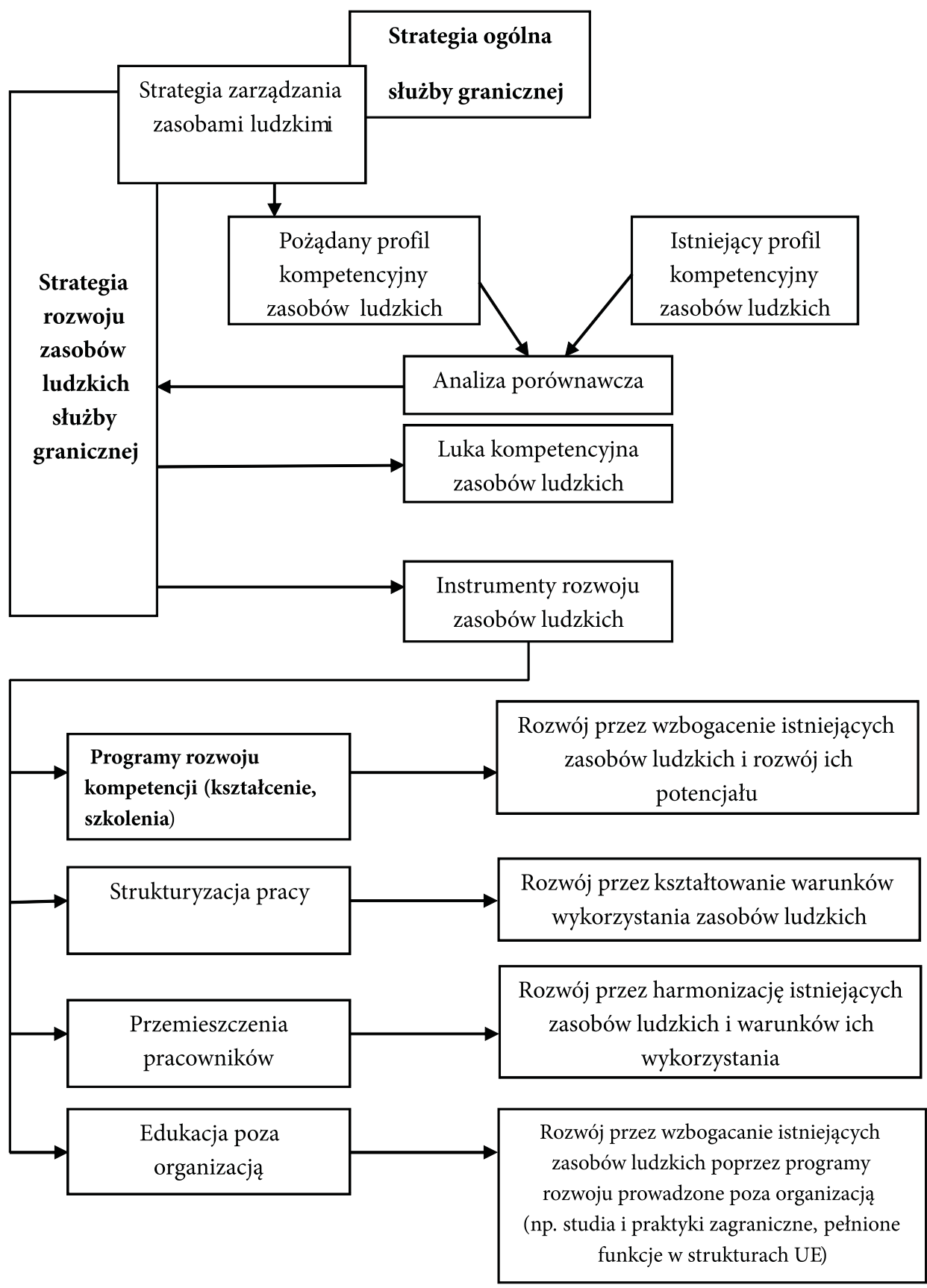

Rys. 1. Instrument rozwoju zawodowego funkcjonariuszy Służby Granicznej RP Źródło: opracowanie własne na podstawie literatury przedmiotu i materiałów źródłowych Służby Granicznej 
Jak wskazują wyniki badań, szkolenia są ważnym instrumentem rozwoju zawodowego pracowników w badanych firmach (Piotrkowski, 2012, s. 162-172).

W zależności od celów szkolenia, w literaturze przedmiotu najczęściej wyróżnia się następujące ich rodzaje:

- szkolenia przygotowujące i wprowadzające do nowej pracy - polegają na przekazaniu nowo zatrudnionym pracownikom wiedzy fachowej, umiejętności i zachowań, których nie można pozyskać poza organizacją;

- szkolenia dostosowawcze - ich celem jest pogłębianie i poszerzanie profesjonalnej wiedzy, umiejętności oraz postaw, aby przygotować pracownika do nowych wymagań związanych z zawodem lub do objęcia innego stanowiska pracy;

- szkolenia przekwalifikowania zawodowego - polegają na uzyskaniu przez pracownika nowej profesji, specjalizacji zawodowej. Takie szkolenia stosowane są w procesach radykalnych zmian organizacyjnych, które związane są z likwidacją stanowisk pracy.

\section{Metody i techniki szkolenia oraz ich charakterystyka}

W działalności organizacji w zakresie szkolenia pracowników wykorzystuje się różnorodne metody oraz techniki szkolenia i doskonalenia zawodowego. Przy ich wyborze najczęściej należy się kierować celami i przedmiotami szkolenia. Wybrane metody szkolenia mają inspirować pracowników do poprawy efektywności, zachęcać, czyli motywować do aktywnego uczestnictwa w szkoleniu, jak również ułatwiać przyswajanie nowej wiedzy, która w przyszłości będzie wykorzystana w miejscu pracy (Piotrkowski, Kolczyńska, 2009, s. 211-221). W literaturze przedmiotu szkolenia klasyfikowane są według różnych kryteriów. Taką koncepcję ze względu na sposób i tryb przekazywania wiedzy prezentują autorzy H. Król i A. Ludwiczyński, dokonując podziału na (Król, Ludwiczyński, 2006, s. 464-465):

- szkolenia pasywne (tradycyjne) i aktywne (aktywizujące), ze względu na sposób uczenia się uczestników;

- szkolenia indywidualne i grupowe, ze względu na skład uczestników;

- szkolenia na stanowisku pracy (on the job training) i poza stanowiskiem pracy (off the job), ze względu na miejsce szkolenia;

- szkolenia informacyjno-pokazowe, symulacyjne i szkolenie w działaniu.

Dobór odpowiednich metod i technik szkolenia decyduje o ich efektywności. Dlatego też nowoczesne organizacje w procesie tym wykorzystują wiele różnorodnych metod i technik, które są dla nich najbardziej odpowiednie. Dokonując określonej klasyfikacji, należy przyjąć odpowiednie kryteria, między innymi takie jak: cel szkolenia, skład uczestników szkolenia, miejsce szkolenia, wymagany stopień zaangażowania ze strony uczestników, liczebności grupy szkoleniowej. 
W publikacjach z zakresu zarządzania zasobami ludzkimi najczęściej wymieniane są metody i techniki uwzględniające podejście indywidualne i grupowe $\mathrm{z}$ włączeniem miejsca szkolenia, czyli na stanowisku pracy i poza miejcem pracy. Wybór odpowiedniej (konkretnej) metody czy techniki szkoleniowej zależy również od treści szkolenia, podmiotu szkolonego, podmiotu prowadzącego szkolenie, kosztów szkolenia oraz doświadczenia w prowadzeniu szkoleń.

Jednym z kryteriów podziału szkoleń jest ich podział na metody i formy szkolenia pracowników $\mathrm{w}$ miejscu i poza miejscem pracy z uwzględnieniem podejścia indywidualnego i grupowego (tabela 1).

Tabela 1. Metody i techniki szkolenia zawodowego w przedsiębiorstwie

\begin{tabular}{|c|c|c|}
\hline & Na stanowisku pracy (on the job) & Poza stanowiskiem pracy (off the job) \\
\hline Indywidualne & $\begin{array}{l}\text { - } \quad \text { coaching (patronat), } \\
\text { - } \quad \text { instruktaż, } \\
\text { - } \quad \text { rotacje na stanowiskach, } \\
\text { - } \quad \text { zastępstwo na stanowiskach pracy, } \\
\text { - } \quad \text { konsultacje z przełożonym. }\end{array}$ & $\begin{array}{l}\text { - } \quad \text { e-learning, } \\
\text { - } \quad \text { techniki audiowizualne, } \\
\text { - } \quad \text { podudia (zaoczne, podyplomowesyacyne, } \\
\text { - } \quad \text { analiza przypadków, } \\
\text { - } \quad \text { zaprogramowany instruktaż, } \\
\text { - } \\
\text { prace pisemne. }\end{array}$ \\
\hline Grupowe & $\begin{array}{l}\text { - } \text { grupowe formy pracy, } \\
\text { - udział w pracach projektowych. }\end{array}$ & $\begin{array}{ll}\text { - } & \text { wykłady, } \\
\text { - } & \text { dyskusje, } \\
\text { - } & \text { seminaria, } \\
\text { - } & \text { gryferencje, } \\
\text { - } & \text { analiza przyulac, } \\
\text { - } & \text { trening grupowy (w tym kierow- } \\
& \text { niczy), } \\
\text { - } & \text { trening wrażliwości, } \\
\text { - } & \text { blended learning, } \\
\text { - } & \text { kurs „na świeżym powietrzu”. }\end{array}$ \\
\hline
\end{tabular}

Źródło: opracowanie własne na podstawie: L. Kozioł, A. Piechnik-Kurdziel, J. Kopeć, Zarzązanie zasobami ludzkimi w firmie. Teoria i praktyka, Wydawnictwo „Biblioteczka Pracownicza”, Warszawa 2000, s. 180, cyt. za A. Pocztowski, Zarządzanie zasobami ludzkimi. Zarys problematyki i metod, Wydawnictwo Antykwa, Kraków 1998, s. 229, K. Piotrkowski, System zarządzania ludźmi w siłach zbrojnych RP, WAT, Warszawa 2012, s. 267

Przedstawione wyżej metody i techniki szkolenia zostały scharakteryzowane pod względem ich praktycznej przydatności w działalności organizacji (tabela 2).

Szkolenie pracowników jest istotnym instrumentem ich rozwoju zawodowego, co przekłada się na efektywne funkcjonowanie organizacji. Głównym celem jest systematyczna zmiana zachowania wiedzy i umiejętności poprzez uczenie się (Misztal, 2006, s. 125). Ogólna charakterystyka wybranych i najczęściej stosowanych metod i technik szkolenia stosowanych w organizacjach znajduje się w tabeli 2. 
Tabela 2. Charakterystyka wybranych metod i technik szkolenia

\begin{tabular}{|c|c|}
\hline $\begin{array}{l}\text { Nazwa metody } \\
\text { lub techniki }\end{array}$ & Charakterystyka \\
\hline Wykład & $\begin{array}{l}\text { Przekazywanie wiedzy w formie słownej (ex katedra), wspartej prezentacjami } \\
\text { multimedialnymi. Metoda przeznaczona dla pracowników na stanowiskach } \\
\text { nierobotniczych. Bierne uczestnictwo szkolonych pracowników w zajęciach. } \\
\text { Jest mało przydatna dla rozwijania kompetencji. Brak możliwości uwzględ- } \\
\text { niania indywidualnych potrzeb uczestników szkolenia. }\end{array}$ \\
\hline Konferencja & $\begin{array}{c}\text { Umożliwia pracownikom dużych firm, zwykle menedżerom i specjalistom, } \\
\text { nawiązanie kontaktów z ekspertami, naukowcami, doradcami, którzy zapra- } \\
\text { szani są jako goście spoza firmy. Na konferencjach uczestnicy stykają się z no- } \\
\text { wymi koncepcjami i doświadczeniami. }\end{array}$ \\
\hline Seminarium & $\begin{array}{l}\text { Jest metodą szkoleniową poza stanowiskiem pracy. Udział w seminarium } \\
\text { umożliwia szkolonym spotkania z ludźmi z innych wydziałów czy też organi- } \\
\text { zacji. Spotkania stanowią okazję do przedyskutowania problemów pojawiają- } \\
\text { cych się w trakcie aktualnie realizowanych projektów. Zadaniem prowadzące- } \\
\text { go seminarium jest umiejętne pokierowanie dyskusją i udzielenie wskazówek } \\
\text { nie tyle o charakterze merytorycznym, ile metodologicznym. }\end{array}$ \\
\hline $\begin{array}{l}\text { Zaprogramowany } \\
\text { instruktaż }\end{array}$ & $\begin{array}{l}\text { Charakteryzuje się tym, że rolę podmiotu szkolącego przejmuje program } \\
\text { komputerowy, który przekazuje informacje, stawia pytania i kontroluje po- } \\
\text { prawność odpowiedzi. Zaletą tej metody jest to, że uczestnik szkolenia samo- } \\
\text { dzielnie może ustawić stopień trudności oraz tempo i czas przebiegu procesu } \\
\text { szkolenia. Zaprogramowany instruktaż doskonale sprawdza się w sytuacjach, } \\
\text { kiedy pojawiają się trudności ze znalezieniem kompetentnych osób, które } \\
\text { mogłyby przeprowadzić szkolenie (wykładowcy, trenerzy) oraz gdy grupa } \\
\text { objęta szkoleniem jest rozproszona przestrzennie. }\end{array}$ \\
\hline $\begin{array}{c}\text { Rotacja stanow- } \\
\text { isk }\end{array}$ & $\begin{array}{l}\text { Jest określana jako systematyczna zmiana czynności wykonywanych przez } \\
\text { pracownika, która polega na planowanej zmianie stanowiska pracy w ramach } \\
\text { istniejącego podziału pracy. Rotacja obejmuje: rozpoznanie możliwości i ce- } \\
\text { lowości zmiany stanowisk pracy; wybór stanowisk i pracowników; budowę } \\
\text { harmonogramu pracy zmianowej; specjalistyczny instruktaż i szkolenie od- } \\
\text { nośnie do celu rotacji; wdrożenie i zanikającą kontrolę. }\end{array}$ \\
\hline Coaching & $\begin{array}{l}\text { Jest to odpowiednio zaplanowana i przeprowadzona metoda szkolenia pra- } \\
\text { cownika przez odpowiedniego trenera (tzw. jeden na jednego), polegająca } \\
\text { na rozwoju wiedzy, umiejętności i postaw uczącego się w celu zwiększenia } \\
\text { jego indywidualnego (i organizacji) kapitału ludzkiego. Coaching polega na } \\
\text { dzieleniu się przez kierownika (coaching wewnętrzny) wiedzą z podległy- } \\
\text { mi mu pracownikami, pomaganiu im i udzielaniu wskazówek dotyczących } \\
\text { wykonywania określonych zadań. Rolę trenera może odgrywać także osoba } \\
\text { z zewnątrz - profesjonalny doradca (coaching zewnętrzny). }\end{array}$ \\
\hline Mentoring & $\begin{array}{l}\text { Polega na wspieraniu w rozwoju młodszego, mniej doświadczonego pracow- } \\
\text { nika przez bardziej doświadczonego kolegę - mentora. Do najczęstszych form } \\
\text { mentoringu można zaliczyć: zachęcanie, udzielanie rad, informację zwrotną, } \\
\text { promowanie oraz monitorowanie sukcesów. Mentor jest odpowiedzialny za } \\
\text { wspieranie w rozwoju swojego podopiecznego, dzieli się z nim swoim doświad- } \\
\text { czeniem i wiedzą. Metoda ta opiera się na zaufaniu, szczerości, a niekiedy nawet } \\
\text { na dyskrecji w stosunku mentor - osoba ucząca się. Mentoring może być za- } \\
\text { równo formalnym, jak i nieformalnym związkiem mentora z osobą mu powie- } \\
\text { rzoną przez organizację lub powstałym z inicjatywy mentora. }\end{array}$ \\
\hline
\end{tabular}




\begin{tabular}{|c|c|}
\hline $\begin{array}{l}\text { Nazwa metody } \\
\text { lub techniki }\end{array}$ & Charakterystyka \\
\hline Zadania zlecone & $\begin{array}{l}\text { Metoda dająca pracownikowi szansę sprawdzenia się w pracy wykraczającej } \\
\text { poza jego rutynowe obowiązki. Polega ona na powierzaniu pracownikowi do } \\
\text { wykonania specjalnych zadań wychodzących często poza zakres normalnych } \\
\text { obowiązków. }\end{array}$ \\
\hline $\begin{array}{l}\text { Udzial w pracach } \\
\text { projektowych }\end{array}$ & $\begin{array}{l}\text { Polega na okresowym przydzieleniu szkolonego do zespołu zadaniowego } \\
\text { pracującego nad określonym projektem. Prace projektowe dają szkolonemu } \\
\text { możliwość nabycia wiedzy fachowej z różnych dziedzin oraz pogłębienia } \\
\text { swoich umiejętności interpersonalnych. }\end{array}$ \\
\hline Wzorow & $\begin{array}{c}\text { Naśladowanie przez młodych pracowników, którzy rozwijają swoje kompe- } \\
\text { tencje, pracowników doświadczonych. Ta technika szkolenia jest najczęściej } \\
\text { stosowana w obsłudze maszyn i urządzeń. }\end{array}$ \\
\hline $\begin{array}{l}\text { Specjalistyczny } \\
\text { instruktaż }\end{array}$ & $\begin{array}{l}\text { Stosowany jest podczas zapoznawania pracowników z określonymi zadaniami } \\
\text { (okres adaptacji, nowe czynności). Doświadczony pracownik - instruktor - } \\
\text { pokazuje lub wyjaśnia pracownikowi, na czym mają polegać jego nowe obo- } \\
\text { wiązki, a następnie osoba szkolona samodzielnie wykonuje zaobserwowane } \\
\text { działania. Takie szkolenie dotyczy najczéściej wykonywania czynności manu- } \\
\text { alnych, pracy biurowej, programowania komputerowego, pomocy lekarskiej. }\end{array}$ \\
\hline $\begin{array}{l}\text { Konsultacje } \\
\text { z przełożonym }\end{array}$ & $\begin{array}{c}\text { Polegają na systematycznym i sterowanym przekazywaniu doświadczenia } \\
\text { zawodowego przez kierowników swoim przyszłym następcom. Kierownicy } \\
\text { odgrywają w ten sposób rolę tzw. trenerów rozwoju, która jest współcześnie } \\
\text { jedną z naczelnych ról kierowania w organizacji. }\end{array}$ \\
\hline $\begin{array}{l}\text { Analiza } \\
\text { przypadków }\end{array}$ & $\begin{array}{l}\text { W analizie przypadków (case study) na przykładzie konkretnych sytuacji z róż- } \\
\text { nych dziedzin funkcjonowania przedsiębiorstwa formułowane są określone } \\
\text { problemy. Na początku dostarczane są pewne informacje o poruszanym proble- } \\
\text { mie, a następnie uczestnicy szkolenia analizują przedstawione materiały i pro- } \\
\text { ponują rozwiązania, które są omawiane. Analiza przypadku najczęściej bazuje } \\
\text { na sytuacji rzeczywistej, z opisu której usunięto pewne istotne szczegóły. }\end{array}$ \\
\hline $\begin{array}{l}\text { Techniki audiowi- } \\
\text { zualne }\end{array}$ & $\begin{array}{l}\text { W technikach audiowizualnych wykorzystuje się rzutniki, slajdy, wideo. Do } \\
\text { metod audiowizualnych zalicza się filmy, telewizję wewnętrzną, kasety wi- } \\
\text { deo. Techniki audiowizualne zwykle stosowane są w połączeniu z wykładem, } \\
\text { w celu zademonstrowania przykładów z życia. }\end{array}$ \\
\hline $\begin{array}{l}\text { Kurs „na świe- } \\
\text { żym powietrzu” } \\
\text { (outdoor courses) }\end{array}$ & $\begin{array}{c}\text { Jest to szkolenie poza miejscem pracy, często w ekstremalnych i trudnych } \\
\text { warunkach terenowych. Sprzyja integracji grupy, pozwala ocenić zdolności } \\
\text { współpracy, skłonności do podejmowania ryzyka, umiejętności grupo- } \\
\text { wego podejmowania decyzji oraz grupowego rozwiązywania problemów. } \\
\text { Umożliwia wyłowienie (zidentyfikowanie) przywódców. }\end{array}$ \\
\hline $\begin{array}{c}\text { Trening } \\
\text { wrażliwości }\end{array}$ & $\begin{array}{c}\text { Metoda stosowana przy doskonaleniu umiejętności kierowniczych. Zajęcia } \\
\text { prowadzone są przez psychologa - mają na celu rozwinięcie umiejętności } \\
\text { interpersonalnych grupy szkoleniowej. Uczenie będące wynikiem doświad- } \\
\text { czenia i przeżywania przebiega w trzech etapach odpowiadających klasyczne- } \\
\text { mu modelowi zmiany Scheina-Lewina, tj. rozmrażania, uczenia się (zmiany) } \\
\text { i zamrażania. }\end{array}$ \\
\hline $\begin{array}{l}\text { Trening } \\
\text { potencjału kier- } \\
\text { owniczego }\end{array}$ & $\begin{array}{l}\text { Obejmuje zestaw różnych technik wykorzystywanych przez trenera do dosko- } \\
\text { nalenia potencjału kierowniczego menedżerów. Do znanych technik należą: } \\
\text { techniki relaksacyjne, techniki odgrywania ról, gry kierownicze. }\end{array}$ \\
\hline
\end{tabular}




\begin{tabular}{|c|c|}
\hline $\begin{array}{l}\text { Nazwa metody } \\
\text { lub techniki }\end{array}$ & Charakterystyka \\
\hline $\begin{array}{l}\text { Techniki relak- } \\
\text { sacyjne }\end{array}$ & $\begin{array}{l}\text { Polegają na kształtowaniu umiejętności słuchaczy w kontrolowaniu stresu to- } \\
\text { warzyszącego pracy menedżera oraz relaksowaniu się po wyczerpującej pracy. } \\
\text { Przykładem technik relaksacyjnych będą: trening analityczny według Jacobso- } \\
\text { na, trening autogenny Schulza oparty na sugestii oraz techniki medytacyjne. }\end{array}$ \\
\hline $\begin{array}{l}\text { Techniki integra- } \\
\text { cyjne }\end{array}$ & $\begin{array}{l}\text { Ich celem jest wywołanie poczucia przynależności do grupy. W tym celu wyko- } \\
\text { rzystywane są przez trenera ćwiczenia zabawowo-relaksacyjne, które ułatwiają } \\
\text { kontakt, uwrażliwiają oraz kształtują zaufanie do innych członków grupy. }\end{array}$ \\
\hline Gry i symulacje & $\begin{array}{c}\text { Zwane inaczej grami symulacyjnymi. W podejściu tym uczestnicy szkolenia } \\
\text { posługują się uproszczonymi schematami rzeczywistości odtwarzającymi sy- } \\
\text { tuacje przedsiębiorstwa lub jego części. Uczą się, wykonując zadania podobne } \\
\text { do czynności zawodowych na sztucznie tworzonych stanowiskach pracy. } \\
\text { Symulacje w procesie szkolenia zapewniają bezpieczeństwo uczestnikom oraz } \\
\text { pozwalają na uniknięcie zbytecznych kosztów, jakie mogłyby zostać poniesio- } \\
\text { ne podczas ćwiczeń w warunkach realnych. }\end{array}$ \\
\hline E-learning & $\begin{array}{l}\text { Polega na wykorzystywaniu Internetu i intranetów (sieci wewnątrz instytucji) } \\
\text { w procesie szkoleniowym. Ta technika szkolenia charakteryzuje się niskimi } \\
\text { kosztami, dużą elastycznością w zakresie aktualizowania treści programów } \\
\text { szkoleniowych oraz możliwością indywidualnego uczenia się. E-learning } \\
\text { służy pozyskiwaniu i przekazywaniu wiedzy, kompetencji i umiejętności. }\end{array}$ \\
\hline Blended learning & $\begin{array}{l}\text { Metoda blended learning łączy to, co najlepsze w e-learningu i w tradycyjnych } \\
\text { formach nauczania. Jest z powodzeniem stosowana zarówno przed rozpoczę- } \\
\text { ciem szkolenia, w jego trakcie, jak i po zakończeniu, gdy przychodzi czas we- } \\
\text { ryfikacji zdobytej wiedzy w codziennej pracy zawodowej. Pozwala w elastycz- } \\
\text { ny sposób budować proces szkoleniowy z uwzględnieniem celów, tematyki, } \\
\text { specyfiki grup, branży. Zyskuje coraz większą popularność przede wszystkim } \\
\text { ze względu na dużą skuteczność szkolenia, szczególnie przy licznych grupach } \\
\text { pracowników uczących się jednocześnie, w krótkim czasie i przy rozproszo- } \\
\text { nej strukturze organizacyjnej, a także pozwala na znaczną redukcję kosztów. } \\
\text { Umożliwia elastyczną organizację całego procesu kształcenia, znacznie pod- } \\
\text { nosząc komfort nauki uczących i uczących się. }\end{array}$ \\
\hline
\end{tabular}

Źródło: Opracowanie własne na podstawie: L. Kozioł, A. Piechnik-Kurdziel, J. Kopé, Zarzadzanie zasobami ludzkimi w firmie. Teoria i praktyka, Wydawnictwo „Biblioteczka Pracownicza”, Warszawa 2000, s. 180, cyt. za A. Pocztowski, Zarządzanie zasobami ludzkimi. Zarys problematyki i metod, Wydawnictwo Antykwa, Kraków 1998, s. 229. A. Szałkowski (red.), Rozwój personelu. Przesłanki, cele, instrumenty, Wyd. Petit, Warszawa 2002, s. 60-57. Cz. Zając, Zarządzanie zasobami ludzkimi, Wyd. Wyższej Szkoły Bankowej, Poznań 2007, s. 188-190, [w:] K. Piotrkowski, System zarządzania ludźmi w Siłach Zbrojnych RP, WAT, Warszawa 2012, s. 268-270

\section{Proces szkolenia funkcjonariuszy Straży Granicznej}

Celem szkolenia funkcjonariuszy Straży Granicznej jest przygotowanie kadr do realizacji zadań ustawowych ${ }^{1}$. W zarządzeniu tym zakłada się wykształcenie

1 Szkolenie w polskiej Straży Granicznej odbywa się na podstawie Zarządzenia nr 106 Komendanta Głównego Straży Granicznej z dnia 19 grudnia 2014 r. w sprawie zakresu oraz szczegółowych zasad szkolenia funkcjonariuszy i pracowników Straży Granicznej. 
funkcjonariuszy wszechstronnie przygotowanych do ochrony granicy państwowej i kontroli ruchu granicznego. Przedmiotowy model nie przewiduje szkolenia funkcjonariuszy w wąskich specjalnościach. Uwzględniono w nim uwagi i spostrzeżenia wynikające $\mathrm{z}$ funkcjonowania dotychczasowego modelu kształcenia w formacji, opinie pionów merytorycznych nadzorujących ochronę granicy państwowej oraz kontakty z przedstawicielami Unii Europejskiej.

W zasadniczych założeniach tej koncepcji ujęto:

- stacjonarne formy kształcenia;

- przeprowadzanie szkoleń $\mathrm{w}$ cyklach - dwa razy w roku, następujących bezpośrednio po zakończonym naborze do służby;

- możliwość samodzielnego ubiegania się funkcjonariuszy o przyjęcie na niektóre etapy szkolenia - szkolenie chorążych, podyplomowe studium oficerskie oraz szkolenia doskonalące.

Wszyscy przyjęci do służby funkcjonariusze, bez względu na poziom wykształcenia, obowiązkowo przechodzą etap szkolenia podstawowego, a następnie odbywają kolejne szkolenia. Tak określone fazy umożliwiają selekcję słuchaczy w wyniku przeprowadzonych na zakończenie egzaminów. Modelowe ujęcie szkolenia i doskonalenia funkcjonariuszy Straży Granicznej przedstawiono na rysunku nr 2. Jak już wcześniej wspomniano, szkolenie pracowników przynosi wymierne korzyści dla organizacji i samego funkcjonariusza (pracownika).

Kandydaci na funkcjonariuszy, którzy przybyli do służby w Straży Granicznej z zawodowym wykształceniem wojskowym, policyjnym, pożarniczym lub podobnym, podlegają przeszkoleniu na poziomie podstawowym według odrębnego programu, który uwzględnia ich dotychczasowe doświadczenie i przygotuje do zawodu funkcjonariusza Straży Granicznej. Po pomyślnym odbyciu pierwszego etapu szkolenia i dobrych wynikach pracy, w zależności od posiadanego stopnia i wykształcenia, kandydaci mogą uczestniczyć w kolejnych etapach rozwoju zawodowego, czyli szkole podoficerskiej, kolejno szkole chorążych oraz podyplomowym studium oficerskim.

Jak wynika z przedstawionego schematu, są dwie ścieżki rozwoju zawodowego w służbie granicznej w zależności od posiadanego wykształcenia. Mamy na myśli wykształcenie średnie bądź wyższe.

Pierwsza ścieżka dotyczy osób posiadających wykształcenie wyższe (rys. 3). Po przejściu pięciomiesięcznego obowiązkowego szkolenia podstawowego kandydaci mogą być skierowani na trzymiesięczny kurs do szkoły chorążych i kolejno na dwunastomiesięczne szkolenie do Podyplomowego Studium Oficerskiego do Służby Granicznej. Warunkiem jest to, że kandydaci na oficerów Straży Granicznej po pozytywnym zaliczeniu szkolenia podstawowego odbywają szkolenie w zakresie szkoły chorążych. Natomiast dopiero po przejściu do służby stałej funkcjonariusz może być skierowany przez jednostki organizacyjne Straży Granicznej na podyplomowe studium oficerskie. 


\section{NABÓR}

(jednostka macierzysta, komisja kwalifikacyjna)

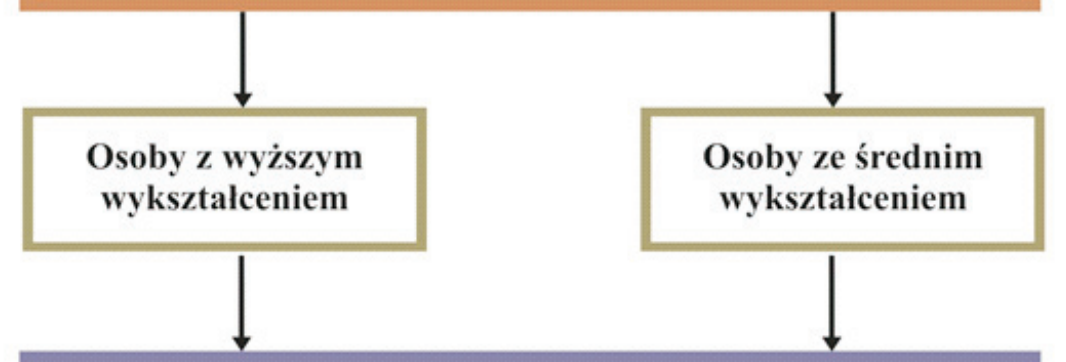

SZKOLENIE PODSTAWOWE

(5 miesięcy w Szkole Straży Granicznej)

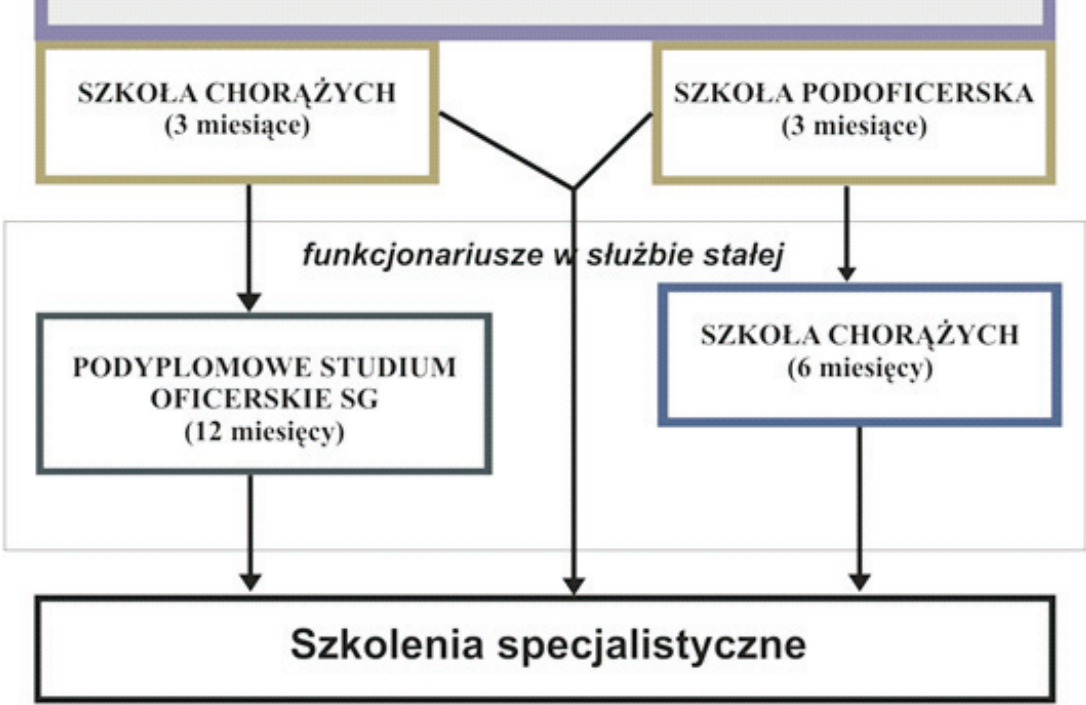

\section{Kursy doskonalące}

Rys. 2. Ogólny model szkolenia zawodowego i doskonalenia funkcjonariuszy Straży Granicznej Źródło: opracowanie na podstawie materiałów źródłowych Straży Granicznej RP oraz pracy końcowej G. Olszowskiego, Szkolenie funkcjonariuszy straży granicznej jako istotny instrument rozwoju kapitału ludzkiego, Wyd. Studia Podyplomowe z Zarządzania Zasobami Ludzkimi, WAT, 2017 


\section{NAB Ó R \\ osoby z wyższym wyksztalceniem}
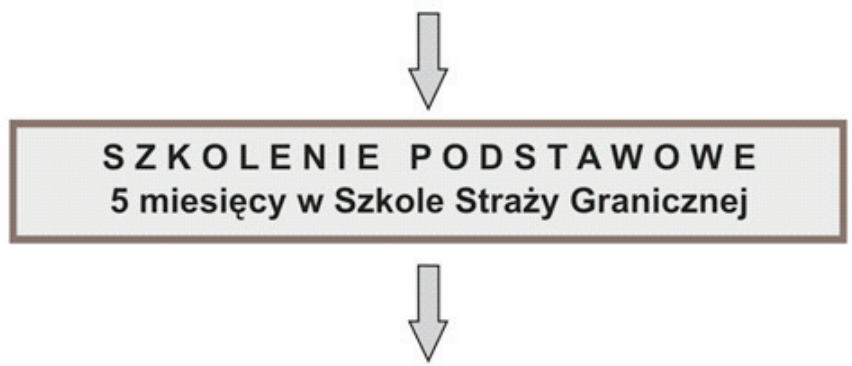

\section{SZKOヒA CHORAZZYCH 3 miesiące}

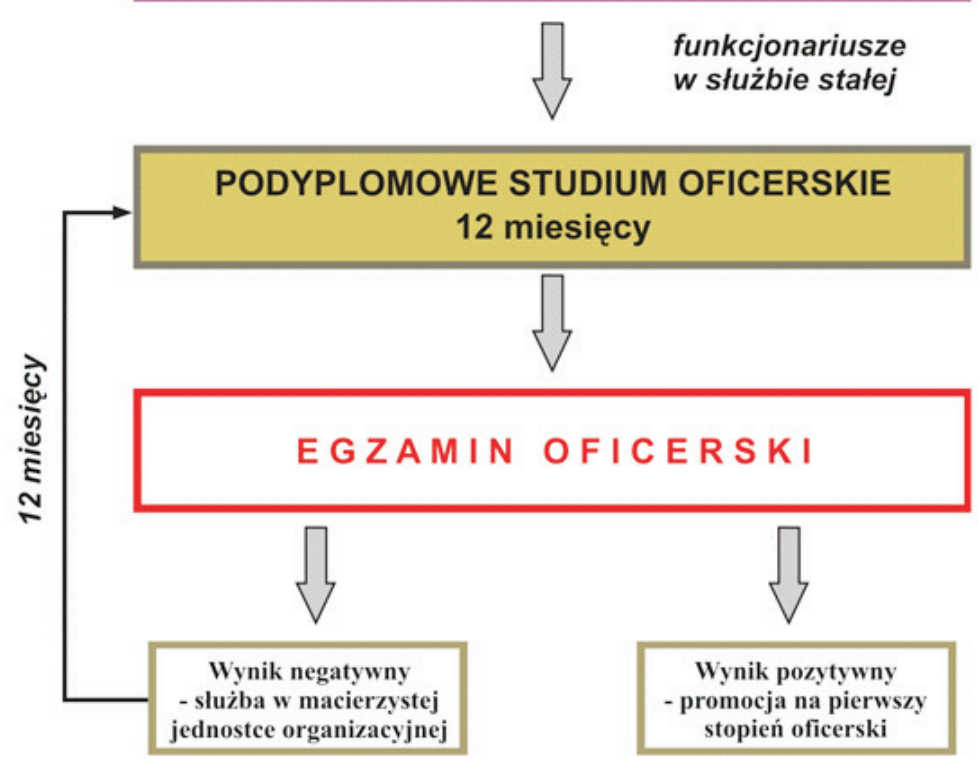

Rys. 3. Ścieżka kariery funkcjonariuszy Straży Granicznej posiadających wyższe wykształcenie Źródło: opracowanie na podstawie materiałów źródłowych Straży Granicznej RP oraz G. Olszowski G., praca końcowa pt. Szkolenie funkcjonariuszy straży granicznej jako istotny instrument rozwoju kapitatu ludzkiego, Wyd. Studia Podyplomowe z Zarządzania Zasobami Ludzkimi, WAT, 2017

Druga ścieżka rozwoju zawodowego jest przewidziana dla osób posiadających wykształcenie średnie (rys. 4). Osoby takie mogą być skierowane do szkoły podoficerskiej w celu odbycia trzymiesięcznego kursu jako wymóg przejścia do tego korpusu zawodowego. Kolejnym etapem będzie sześciomiesięczny kurs w szkole chorążych. Należy podkreślić, że do szkoły oficerskiej i szkoły chorążych są kierowani kandydaci 
(funkcjonariusze) służby stałej. W tym modelowym ujęciu (systemie szkolenia) nie przewiduje się specjalnego podsystemu dla osób przyjmowanych na specjalistyczne stanowiska, takie jak: radca prawny, lekarz itp. W takich przypadkach zatrudnia się pracownika cywilnego z uposażeniem odpowiadającym posiadanym kwalifikacjom i adekwatnym do proponowanego stanowiska.

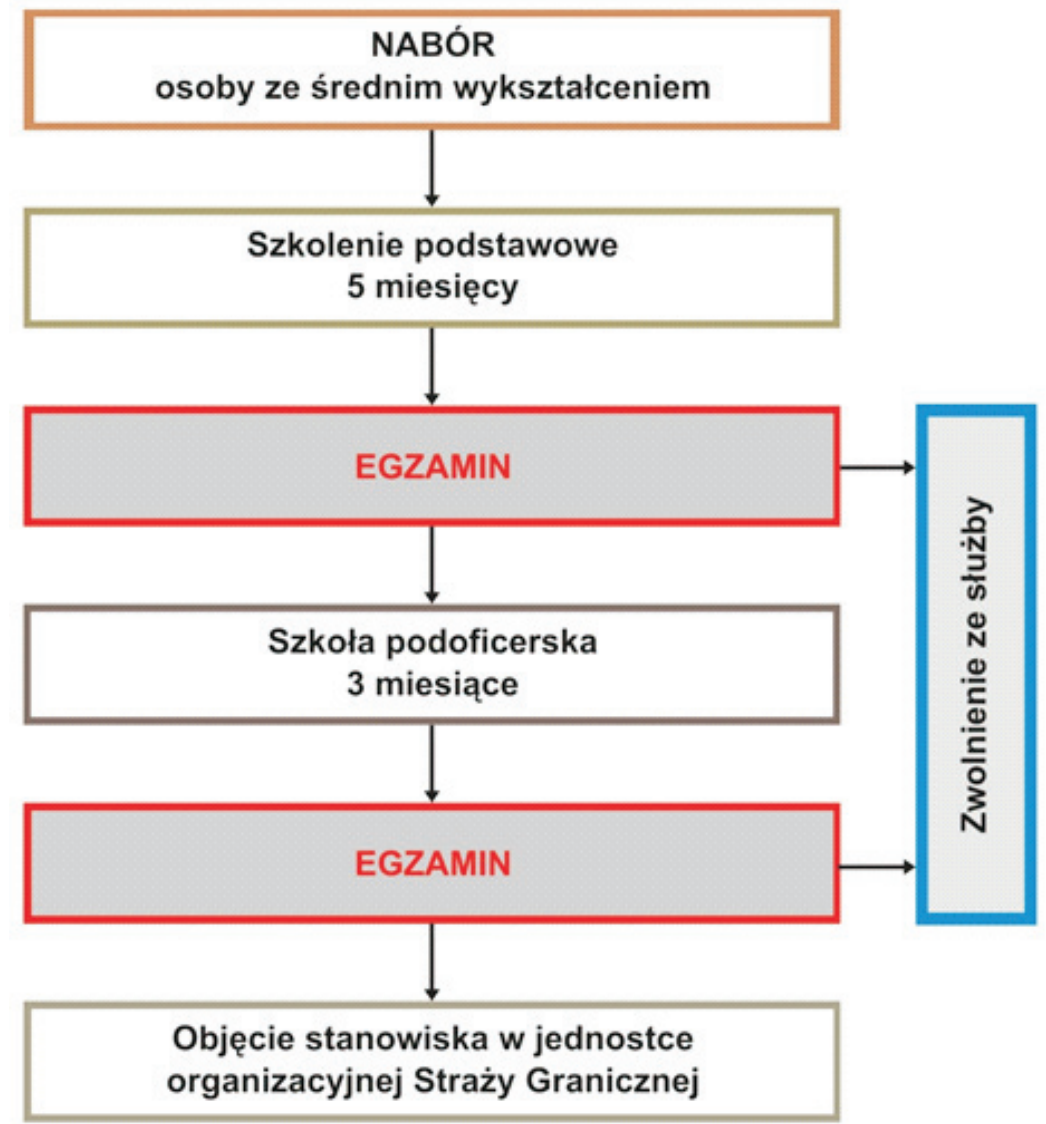

Rys. 4. Ścieżka kariery funkcjonariuszy Straży Granicznej posiadających średnie wykształcenie Źródło: opracowanie na podstawie materiałów źródłowych Straży Granicznej RP oraz G. Olszowski, praca końcowa pt. Szkolenie funkcjonariuszy straży granicznej jako istotny instrument rozwoju kapitału ludzkiego, Wyd. Studia Podyplomowe z Zarządzania Zasobami Ludzkimi, WAT, 2017

Funkcjonariusze Straży Granicznej w trakcie pełnienia służby (po ukończeniu określonych szkoleń) najczęściej są kierowani przez kierowników jednostek organizacyjnych Straży Granicznej na szkolenia specjalistyczne lub z własnej inicjatywy mogą uczestniczyć w kursach doskonalących w ośrodkach szkoleniowych Straży Granicznej lub poza nią. Kandydaci mogą być rekrutowani z zewnątrz i z samej formacji. 


\section{Rodzaje i zakres szkolenia funkcjonariuszy Straży Granicznej}

Szkolenia funkcjonariuszy Straży Granicznej realizowane są na różnych poziomach i w różnym zakresie w zależności od posiadanego poziomu wykształcenia i doświadczenia zawodowego w służbie granicznej, wojsku bądź policji, oczywiście mając na uwadze ścieżki rozwoju zawodowego w Straży Granicznej.

Rozpoczynając od poziomu najwyższego: $\mathrm{w}$ ramach podyplomowego studium oficerskiego Służby Granicznej celem jest przede wszystkim wykształcenie umiejętności kierowania podległym zespołem w roli kierownika zmiany oraz zastępcy komendanta placówki Straży Granicznej. W szczególności słuchacze poznają techniki organizacji ochrony granicy państwowej, zasady kierowania działaniami granicznymi, wystawiania wiz, readmisji oraz zastosowanie prawa karnego, administracyjnego i praw człowieka. Zagadnienia te są przedmiotem szkolenia, które trwa dziesięć miesięcy. Na zakończenie cyklu zajęć przeprowadza się egzamin oficerski. Pozostałe dwa miesiące przeznacza się na praktykę na przyszłym stanowisku pracy, co w sposób pożądany zweryfikuje możliwości kandydata (jest to również czas konieczny na przygotowanie procedury promocyjnej).

Szkolenie w szkole chorążych trwa sześć miesięcy. Celem szkolenia jest nabycie przez słuchaczy umiejętności kierowania grupą, doskonalenie pełnienia służby granicznej i kontroli ruchu granicznego wraz z czynnościami wizowymi oraz prowadzenie czynności procesowych (np. przyjęcie zawiadomienia o przestępstwie, przesłuchanie świadka) i doskonalenie czynności dowodowych. Na zakończenie szkolenia słuchacze zdają egzamin, którego pozytywny wynik potwierdza ich kwalifikacje do objęcia stanowisk dowódcy drużyny granicznej, kontrolera, przewodnika psa służbowego lub innego przewidzianego dla chorążych Straży Granicznej. Negatywny wynik egzaminu (zarówno w terminie podstawowym, jak i poprawkowym) powoduje, że funkcjonariusz nadal zajmować będzie dotychczasowe stanowisko.

Kształcenie funkcjonariuszy na poszczególnych poziomach jest permanentnie uzupełniane na szkoleniach specjalistycznych i kursach doskonalących.

Szkolenia specjalistyczne przygotowują funkcjonariuszy do wykonywania szczególnych zadań na zajmowanych już przez nich stanowiskach lub stanowiskach, do objęcia których w przyszłości są przewidziani (planowani). Zakres szkoleń specjalistycznych jest różnorodny w zależności od występujących określonych potrzeb. Do takich szkoleń, np. z zakresu służby granicznej, kontroli ruchu granicznego, operacyjno-śledczych i technik kryminalistycznych, należą:

- kształcenie umiejętności kierowniczych dla kadry zarządzającej;

- szkolenie logistyczne (technika i zaopatrzenie, łączność i informatyka);

- szkolenia językowe;

- inne według potrzeb. 
Wymienione szkolenia uwzględniają potrzeby wynikające ze szczebla (poziomu) funkcjonariuszy kierowanych na wniosek ich przełożonych, czyli Straż Graniczną.

Kursy doskonalące stanowią otwartą ofertę szkół w Koszalinie, Kętrzynie i Lubaniu, adresowaną do wszystkich funkcjonariuszy, którzy mogą korzystać z nich, gdy skierują wniosek o uczestniczenie w szkoleniu za pośrednictwem właściwych komórek kadrowych. Oferta szkoleń doskonalących przedstawiana jest na każdy rok szkoleniowy jednostkom organizacyjnym Straży Granicznej w formie cyklicznych seminariów dla kadry kierowniczej w zakresie:

- zmian przepisów prawnych;

- nowych form i metod służby;

- obsługi i eksploatacji sprzętu;

- kursów komputerowych.

Szkolenia i kursy doskonalące stanowią kryterium objęcia stanowisk służbowych, podobnie jak mianowanie na wyższe stopnie, zgodnie z zasadami pragmatyki kadrowej.

\section{Rekomendacje}

Szkolenia i kursy doskonalące są istotnym instrumentem rozwoju zawodowego funkcjonariuszy i jednocześnie integralnym komponentem rozwoju kapitału ludzkiego w Straży Granicznej.

Zasadniczym kryterium jakości kształcenia funkcjonariuszy jest ich profesjonalizm w wykonywaniu funkcji i realizacji zadań odpowiadających standardom oraz wymogom stawianym przez Wspólnotę Europejską.

Ważnym czynnikiem efektywności kształcenia słuchaczy powinno być rozwijanie ich twórczego myślenia, które wiąże się nierozerwalnie $\mathrm{z}$ innowacyjnością, przedsiębiorczością, skutecznością i samodzielnością w działaniu.

W warunkach szybko postępujących zmian społecznych oraz ekonomicznych, zagrożeń migracyjnych i terrorystycznych, a także daleko idących przemian organizacyjnych i merytorycznych $\mathrm{w}$ nauce o zarządzaniu rośnie jednocześnie waga zarządzania wiedzą pracowników.

Współcześnie dużego znaczenia nabiera elastyczność i permanentne doskonalenie kompetencji, a także, co jest znacznie trudniejsze, możliwość przyjęcia nowych wartości czy postaw. Według powszechnej opinii zmianie ulega bądź powinien ulec sposób postrzegania pracownika przez kierownika, w tym sensie, że większego znaczenia nabiera nie posłuszeństwo, ale inicjatywa i szersze spojrzenie.

Rozwój kadr Straży Granicznej dokonuje się poprzez nabywanie pożądanych kompetencji społeczno-zawodowych, tzn. takich, które są lub będą bezpośrednio przydatne na zajmowanym stanowisku służbowym. 
Konieczność uzupełniania kompetencji wynika z ciągłych zmian wymagań wobec służb granicznych, zmian wymagań procesu zarządzania oraz rotacji kadry na stanowiskach.

Rozwój kompetencji jest procesem ciągłym, obejmującym zarówno słuchaczy ośrodków szkolenia, jak i funkcjonariuszy placówek i innych jednostek organizacyjnych.

Należy dążyć do permanentnego rozwoju kapitału ludzkiego, ponieważ w przyszłości to jakość kształcenia funkcjonariuszy pozwoli na przygotowanie profesjonalnej kadry odpowiadającej standardom i wymogom stawianym przez Wspólnotę Europejską.

\section{Podsumowanie}

Profesjonalizacja Straży Granicznej dokonuje się poprzez nabywanie i rozwój pożądanych kompetencji, tzn. takich, które są lub będą bezpośrednio poszukiwane na zajmowanym stanowisku służbowym teraz i w przyszłości. Dlatego też występuje konieczność systematycznego ich uzupełniania (nabywania) poprzez rozwój określonych kompetencji, które wynikają z ciągłych zmian wymagań wobec służb granicznych. Dotyczy to również określonych wymagań co do samego procesu zarządzania nimi będących skutkiem dość częstej rotacji kadry na stanowiskach osób funkcyjnych i wykonawczych. Rozwój kompetencji jest procesem ciągłym, obejmującym zarówno słuchaczy ośrodków szkolenia, jak i funkcjonariuszy placówek i innych jednostek organizacyjnych. Dlatego też należy dążyć do permanentnego rozwoju kompetencji funkcjonariuszy Służby Granicznej w celu przygotowania dobrej kadry odpowiadającej standardom i wymogom stawianym przez Wspólnotę Europejską.

\section{LITERATURA}

[1] Jurczak D., Jakość kształcenia absolwentów Centralnego Ośrodka Szkolenia Straży Granicznej w Koszalinie, „Biuletyn Centralnego Ośrodka Szkolenia Straży Granicznej” nr 1/2006, Koszalin 2006.

[2] KozioŁ L., Piechnik-Kurdziel A., Kopeć J., Zarządzanie zasobami ludzkimi w firmie. Teoria i praktyka, „Biblioteczka Pracownicza”, Warszawa 2000.

[3] KRól H., Ludwiczyński A. (red.), Zarządzanie zasobami ludzkimi, PWN, Warszawa 2006.

[4] Misztal J., Człowiek w organizacji, Wydawnictwo Politechniki Śląskiej, Gliwice 2006.

[5] Olszowski G., praca końcowa pt. Szkolenie funkcjonariuszy straży granicznej jako istotny instrument rozwoju kapitatu ludzkiego, Wyd. Studia Podyplomowe z Zarządzania Zasobami Ludzkimi, WAT, 2017.

[6] Ріотккошsкi K., Rozwój zawodowy pracowników w polskich przedsiębiorstwach, [w:] K. Piotrkowski (red.), Zarzadzanie zasobami ludzkimi (teoria i praktyka), monografia, Towarzystwo Naukowe Organizacji i Kierownictwa, Warszawa 2012. 
[7] Piotrкowsкi K., System zarządzania ludźmi w siłach zbrojnych RP, WAT, Warszawa 2012.

[8] Piotrkowski K., KolczyŃska I., Instrumenty rozwoju zawodowego stosowane w firmach zagranicznych, [w:] „Nowoczesne Systemy Zarządzania”, WAT, Warszawa 2009.

[9] Pocztowski A., Zarzadzanie zasobami ludzkimi. Zarys problematyki i metod, Antykwa, Kraków 1998.

[10] Sza£кowski A. (red.), Rozwój personelu. Przesłanki, cele, instrumenty, Petit, Warszawa 2002.

[11] ZająC Cz., Zarządzanie zasobami ludzkimi, Wyd. Wyższej Szkoły Bankowej, Poznań 2007.

[12] Zarządzenie nr 106 Komendanta Głównego Straży Granicznej z dnia 19 grudnia 2014 r. w sprawie zakresu oraz szczegółowych zasad szkolenia funkcjonariuszy i pracowników Straży Granicznej. 